\title{
ПРОБЛЕМА ВІДНОВЛЕННЯ РУХІВ З ПОГЛЯДУ ФУНКЦІОНАЛЬНОї СИСТЕМИ
}

\author{
О. М. Підопригора, М. І. Вовк \\ Міжнародний науково-навчальний центр інформаційних технологій та систем \\ НАН и МОН України
}

\begin{abstract}
С позиции функциональных систем рассмотрено структуру отдельного двигательного акта. На основе нейропластичности нервной системы обоснована технология восстановления движения с помощью электронных устройств как внешних контуров управления.
\end{abstract}

В наш час захворювання нервової системи займають друге місце за інвалідизацією хворих. На особливу увагу заслуговує порушення рухів, що призводить до значного обмеження працездатності та самообслуговування. 70-80 \% хворих, які перенесли ГПМК, стають інвалідами, 20-30 \% потребують стороннього догляду, 80 \% мають рухові розлади. Щорічно реєструється 100-300 випадків захворювання на 100000 населення. Рухова активність $€$ важливою потребою організму, фактором, який обумовлює забезпечення повноцінної життєдіяльності. Серед пацієнтів, які перенесли ГПМК, великий відсоток інвалідизації пов'язаний з порушенням рухів паретичної кінцівки. Ефективною технологією тренування i відновного лікування рухів $€$ біоінформаційна технологія ТРЕНАР і апарати Тренар-01 та Тренар-02, які реалізують технологію. Електронні пристрої Тренар, які засновані на програмній електростимуляції м'язів і використанні біологічного зворотного зв' язку (зорового і слухового) як зовнішні контури керування рухами утворюють разом з власною системою керування нову функціональну систему [1] та виконують роль недостатньої ланки у формуванні нового рухового стереотипу замість спотвореного патологією [2, 3]. У формуванні нового рухового стереотипу, відновленні рухів, велику роль відіграє нейропластичність нервової системи [4].

Метою дослідження є розглянути рух з позиції функціональної системи та обгрунтувати технологію відновлення рухів за допомогою електронних пристроїв як зовнішніх контурів керування на основі нейропластичності нервової системи.

Матеріал і методи дослідження. Предметом дослідження є керовані довільні рухи людини,їх аналіз на різних ланках побудови руху та відновлення пошкодженої функції за рахунок приєднання зовнішнього контуру керування, центральною ланкою якого $\epsilon$ електронний пристрій. Теоретичні дослідження руху як функціональної системи. Розрізняють два основ- них види руху: довільні та не довільні рухи. До не довільних рухів відносять прості автоматичні рухи, які виконуються за рахунок сегментарного апарату спинного мозку та стовбура мозку за типом простого рефлекторного акту. Довільні цілеспрямовані рухи - це акти рухової поведінки людини. Спеціальні довільні рухи (поведінкові, трудові) виконуються за провідною участю кори головного мозку, а також екстрапірамідної системи та сегментарного апарата. Також виконання довільних рухів тісно пов'язане 3 пірамідною системою [4]. При цьому проведення імпульсу нейрона $з$ кори головного мозку до м'язів проходить по ланцюгу, який складається 3 двох нейронів: центрального та периферійного. Довільні рухи належать до найскладніших психічних функцій людини. Фізіологічний підхід, розроблений Н. А. Бернштейном, полягає в особливості аферентних систем. При виконанні руху основна ланка зміщується від аферентних до еферентних систем, сигналізуючи як про положення кінцівки в просторі, так і про стан м'язового апарата, враховуючи «модель потрібного майбутнього». Ця система зворотної аферентації включає в себе зорову аферентацію, систему кінестетичних сигналів, контроль над виконанням дії та корекцію помилкових дій. Внаслідок надходження аферентних сигналів відбувається порівняння параметрів результату дії з наміром (акцептор результату дії за П. К. Анохіним). У людини задні відділи сенсомоторної кори, забезпечуючи еферентну організацію рухів, виділились в постцентральну ділянку. А передні, що беруть участь в еферентній організації рухів, в моторну та премоторну ділянку. А. Р. Лурія ввів додаткове поняття «руховий аналізатор», в склад якого входять не тільки моторні, але й сенсорні та асоціативні кіркові поля. Тому прийнято виділяти аферентну та еферентну сторони в організації рухів [4].

Найдокладніше модель структури поведінки викладено в концепції функціональних систем П. К. Анохіна.

\footnotetext{
(C) О. М. Підопригора, М. І. Вовк
} 
Вивчаючи фізіологічну структуру поведінкового акту, П. К. Анохін прийшов до висновку про необхідність розрізняти часткові механізми інтеграції, коли вони вступають у взаємодію між собою та утворюють складну координовану взаємодію. Вони об'єднуються, інтегруються в систему більш складного порядку, в поєднану архітектоніку пристосовницького, поведінкового акту. Тому функціональна система виділяється як динамічна, саморегулювальна організація, вибірково поєднуючи структури та процеси на основі нервових та гуморальних механізмів регуляції для досягнення корисних системі та організму пристосувальних результатів. П. К. Анохін застосував цей принцип на структуру будь-якої цілеспрямованої поведінки. 3 цих позицій може бути розглянута структура окремого рухового акту.

Функціональні системи мають розгалужений морфофізіологічний апарат, який забезпечує за рахунок присутніх в ній закономірностей як ефект гомеостазу, так і саморегуляції. Існує два типи функціональних систем.

Функціональні системи другого типу використовують зовнішній ланцюг саморегуляції. Вони забезпечують пристосованість за рахунок виходу за межі організму через зв'язок з зовнішнім середовищем. Саме системи другого типу полягають в основі різних поведінкових актів та різних типів поведінки. Рух людини належить до другої функціональної системи [1].

Структура функціональних систем, які обумовлюють цілеспрямовані поведінкові акти різної складності має такий вигляд: аферентний синтез, акцептор результатів дії, еферентний синтез, формування дії, оцінка отриманого результату [ 5 ]. При перенесенні ГПМК з наслідками в вигляді порушення функції рухів пошкоджуються рухові центри кори головного мозку, внаслідок чого страждає еферентний шлях, функціональна система побудови руху не працює втрачається ланка формування дії. Зовнішній контур керування вимушеними рухами під впливом програмної електростимуляції м' язів, стимулює потік зворотної аферентації, який «запускає до дії» інші ланки функціональної системи.

Розглядаючи рух з позиції функціональної системи найменшою ланкою на клітинному рівні $є$ нейрон. Він здатний до структурно-функціональної перебудови. Змінюється функціональна активність його синапсів, їх кількість, проходить формування нових синапсів, змінюється їх конфігурація та розмір активних зон. Встановлено, що повторна стимуляція пресинаптичної мембрани сприяє посиленню або зменшенню впливу на постсинаптичний нейрон. Цей процес дозволяє здійснити динамічний контроль над потоком інформації в нейрональних системах і пояснити наступний феномен, як довготривала потенціація [6]. Довготривала потенціація - це тривале збільшення синаптичної активності після короткочасної інтенсивної стимуляції. В певних випадках така стимуляція викликає різке посилення синаптичної активності з наступним, швидко знижуючим до відправного, рівня активності. Цей механізм є присутнім в гіпокампі та відіграє важливу роль в навчанні та запам'ятовуванні, формуванні навичок. Довготривала потенціація потребує синтезу нових протеїнів та росту нових синаптичних з'єднань, що в свою чергу бере участь в перетворенні «німих» синапсів в активні. При тривалій стимуляції постсинаптична клітинна мембрана генерує новий дендритний шип. Все це є одним з основних механізмів нейропластичності у формуванні клітинної відповіді на пошкодження ЦНС [6]. Таким чином, при зовнішній біолектростимуляції ми створюємо умови для запуску механізмів пластичності нервової тканини, що, в свою чергу, прискорює відновні процеси та формує акцептор результату дії.

При порівнянні результатів відновлення хворих, які перенесли ГПМК з порушенням рухових функцій, iз застосуванням біоелектростимуляції в комплексі реабілітаційних заходів відновлення в дослідній групі проходило в на 40 \% більшому об'ємі, ніж у контрольній. Дослідження проведено на базі неврологічного відділення № 1 Київської міської клінічної лікарні № 3 .

Висновки. Рух є складною функціональною системою, яка утворилась за рахунок тривалого філогенезу та онтогенезу. Важливим завданням при відновленні рухів $є$ не тільки відновлення сили, але й відтворення втраченого рухового навику. Вивчення складових руху з позицій функціональних систем та феномена нейропластичності на макро- та мікроскопічних рівнях дасть змогу керувати потенціалом нервової системи, спрямованим на відновлення рухових функцій, дозволить вдосконалити терапевтичні тактики щодо відновлення втрачених функцій та поліпшення якості життя пацієнтів з захворюваннями та травмами нервової системи. 


\section{Література}

1. Анохин П. К. Очерки по физиологии функциональных систем. - М. : Медицина, 1975.-447 с.

2. Вовк М. И. Биоинформационная технология управления движениями человека // Кибернетика и вычислительная техника. -2010. - Вып. 161.-С. 42-52

3. Гриценко В. И. ТРЕНАРстановления движений / Гриценко В. И., Вовк М. И. // Матеріали Міжнародного науково-практичного форуму «Наука і бізнес - основа розвитку економіки», 11-12 жовтня 2012 року, м. Дніпропетровськ.-С.204-206.
4. Бернштейн Н. А. Современные искания в физиологии нервного процесса / Н. А. Бернштейн. - М. : Смысл, 2003. $-330 \mathrm{c}$.

5. Репина Н. В. Основы клинической психологии / Н. В. Репина, Д. М. Ворнцов, И. И. Юматова. - М. : Высшее образование, 2003.-216 с.

6. Кадыков А. С. Реабилитация неврологических больных / А. С. Кадыков, Л. А. Черникова, Н. В. Шахпаронова. - М. : МЕДпресс-информ, 2009.-509 с. 